\title{
Use of essential oils in combination with fibrolytic enzymes to decrease in vitro ruminal methane production
}

\author{
T.C. Nel, A. Hassen", A.M. Akanmu \& F.A. Adejoro \\ Department of Animal and Wildlife Sciences, University of Pretoria, Pretoria, Private bag X20, Hatfield 0028, South Africa
}

(Submitted 17 February 2020; Accepted 28 July 2020; Published 26 October 2020)

Copyright resides with the authors in terms of the Creative Commons Attribution 4.0 South African Licence.
See: http://creativecommons.org/licences/by/4.0/za
Condition of use: The user may copy, distribute, transmit and adapt work, but must recognise the authors and the South African Journal
of Animal Science.

\begin{abstract}
Exogenous enzymes and essential oils (EOs) have both improved fibre digestion in ruminants, but the effect on ruminal fermentation and methane emission of combining these additives requires further evaluation. Various EOs were used in combination with an enzyme in an in vitro gas production system to measure organic matter digestibility and methane after 48 hours of incubation of Eragrostis curvula. The treatments consisted of T1) unaugmented control; T2) enzyme (cellulose-xylanase mixture, 1:1 w/w, 1.5 $\mathrm{mL} / \mathrm{g}$ DM); T3) enzyme combined with Next Enhance ${ }^{\circledR}$ (cinnamaldehyde with diallyl disulfide and diallyl trisulfide, 43:3.85 w/wt); T4) enzyme and cinnamon oil; T5) enzyme and garlic oil; and T6) enzyme with cinnamon and garlic oil, 1:1 w/w). At 2, 4, 8, 12, 24, 36, and 48 hours of incubation, gas production was measured, and gas samples were analysed for methane concentration. The inclusion of additives affected cumulative gas production $(P<0.05)$, but only slightly affected methane production $(P=0.05)$ after 48 hours of incubation. The addition of enzymes increased both gas and methane production. T5 and T6 both reduced gas production compared with T2. Combining EOs with an enzyme reduced methane production compared with T2 after 48 hours of incubation. The additives tended to increase in vitro organic matter digestibility $(P$ $=0.09$ ), although they showed a tendency towards reduced methane production per unit of organic matter digested $(P=0.07)$. Further studies on these enzyme and EO combinations under different doses and substrates are required to validate their efficacy for ruminant production.
\end{abstract}

Keywords: cinnamon oil, cinnamaldehyde, garlic oil, gas production, glucanase, in vitro digestibility, xylanase

"Corresponding author: Abubeker.hassen@up.ac.za

\section{Introduction}

Efforts to improve growth by natural means have led to increased research into plant-derived compounds and their effects on ruminal fermentation (Calsamiglia et al., 2007). Essential oils are volatile plant secondary metabolites that are currently gaining popularity as ruminant feed additives because they could act as alternatives to traditional antibiotic growth promoters (Wallace, 2004). The yield and composition of EOs from plants of the same species vary and this is responsible for each plant's characteristic flavour and fragrance (Benchaar \& Greathead, 2011). The original role of EOs was to protect plants from abiotic and biotic stressors through their fragrance. They also attract organisms that pollinate and disperse seeds (Wink, 2010). Essential oils have promising effects through selective anti-bacterial activity, inhibition of ruminal methane emissions, enhancement of ruminal propionate proportions, and bypass of protein to the intestine (Benchaar et al., 2007; Calsamiglia et al., 2007). The antibacterial activity of garlic oil has been related to the presence of allicin and diallyl sulfides. Equally, cinnamaldehyde, a major component of cinnamon oil, has shown strong antimicrobial properties through the disruption of cytoplasmic membranes of microbes (Ouwehand et al., 2010; Benchaar \& Greathead, 2011).

Mcintosh et al. (2003) found that EOs inhibit the energy metabolism of rumen microorganisms such as Methanobrevibacter smithii, a rumen archaea that contributes to methane production. The effect of EOs on methane mitigation has been evaluated in vivo and in vitro, but the reported responses in methane production were variable, which may be related to the natural diversity of these compounds (Calsamiglia et al., 2007). Although in vitro screening has proved an effective procedure to identify plant compounds with 
potentially positive effects (Beauchemin et al., 2008), screening of multiple EO combinations and at different dose rates would improve the understanding and application of EOs in ruminant feeding.

Although fibrolytic enzymes have been used successfully to improve rumen fermentation with high forage diets (Van de Vyver \& Cruywagen, 2013), there is an associated increase in methane production because of a higher proportion of acetate in the fermentation product (Gemeda et al., 2014; Gemeda \& Hassen, 2015). In contrast, EOs have been shown to mitigate enteric methane production in vitro and in vivo (Mutavhatsindi et al., 2018). In the rumen, the antimethanogenic properties of EOs can militate against hydrogen, which is produced during acetate formation, being channelled into the methanogenic pathways. It was hypothesized that a combination of fibrolytic enzymes and various EO mixtures would provide an additive effect on rumen fermentation by improving feed digestibility while reducing methane production. The aim of this study therefore was to investigate the effects of cinnamaldehyde, garlic oils and their mixture, with or without fibrolytic enzymes, on in vitro gas and methane production and organic matter digestibility.

\section{Materials and Methods}

This study was conducted at the University of Pretoria's Experimental Farm following a protocol approved by the Animal Ethics Committee of the University of Pretoria (EC057-15).

Eragrostis curvula hay, which was used as substrate for in vitro fermentation, was obtained from a commercial feed mill in Gauteng, South Africa. Substrate samples were dried at $55{ }^{\circ} \mathrm{C}$ for 48 hours in a forced draft oven. For all in vitro studies and chemical composition analyses, the samples were milled through a 1-mm sieve in a Wiley mill (Arthur $\mathrm{H}$. Thomas, Philadelphia, PA, USA). The samples were stored in sealable plastic bags at $4{ }^{\circ} \mathrm{C}$ prior to incubation and analysis. The six experimental treatments consisted of T1) unaugmented control; T2) enzyme (cellulose-xylanase mixture, 1:1 w/w, $1.5 \mathrm{~mL} / \mathrm{g} \mathrm{DM}$ ); T3) enzyme combined with Next Enhance (cinnamaldehyde with diallyl disulfide and diallyl trisulfide (43:3.85 w/wt); T4) enzyme and cinnamon oil; T5) enzyme and garlic oil; and T6) enzyme with cinnamon and garlic oil (1:1 w/w). The enzyme compound in treatments T2-T6 was a commercial product that contained a mixture of two enzymes that consisted of concentrated liquids of acid cellulase (E.C. 3.2.1.4) and acid-neutral endo-1, 4- $\beta$ D-xylanase (E.C. 3.2.1.8), whereas the EO product in T3 was Next Enhance. The cinnamaldehyde and garlic oil were purchased from Sigma-Aldrich (Merck KGaA, Darmstadt, Germany).

Ten $\mathrm{mg}$ of each EO were dissolved in $10 \mathrm{~mL}$ of ethanol and a $1 \mathrm{~mL}$ aliquot of each solution was added to the substrate in incubation vials to give a final concentration of $30 \mathrm{mg} / \mathrm{L}$ with the addition of $33 \mathrm{~mL}$ mixed rumen liquor. The concentrations of garlic oil and cinnamaldehyde were based on previous research (Busquet et al., 2005). All additives were stored at $5^{\circ} \mathrm{C}$ in a smoked glass flask before use (Busquet et al., 2005). For each treatment of enzyme or EO preparation, the required dose rates were diluted to deliver the specific concentration in $1 \mathrm{~mL}$ aliquots. The density of the enzyme and carrier mixture was different from that of water and this was corrected for. A fresh batch of dilutions was prepared for each in vitro incubation run. The amount of $400 \mathrm{mg}$ Eragrostis hay was weighed and $1 \mathrm{~mL}$ of enzyme or EO treatment was added to each $125 \mathrm{~mL}$ serum bottle 24 hours before the start of incubation as pre-treatment of the milled substrate to allow for an enzyme-substrate interaction (Van de Vyver \& Cruywagen, 2013). The control treatment received $1 \mathrm{~mL}$ of distilled water to standardize the volume of liquor in the vials.

Rumen buffer and macro-mineral and micro-mineral solutions were prepared according to Goering and Van Soest (1970) with modifications of Mould et al., (2005) by replacing magnesium sulphate heptahydrate with magnesium chloride in the macro mineral to prevent excess sulphate in the in vitro media. The prepared buffer solution was placed in a water bath at $39^{\circ} \mathrm{C}$ with a constant stream of $\mathrm{CO}_{2}$ until the solution turned colourless. Rumen-cannulated Merino sheep that were used as rumen fluid donors were fed lucerne hay as basal diet ad libitum. Rumen fluid collections were done at $08 \mathrm{~h} 30$ throughout the trial after the morning feeding. Approximately $500 \mathrm{~mL}$ of ruminal fluid was collected from at least three donor animals. Rumen contents were filtered through four layers of cheesecloth into a pre-heated thermos flask. The flask was filled with rumen fluid to maintain anaerobic conditions. In the laboratory, the measured volume of rumen fluid was added to the prepared buffer solution and continuously purged with a stream of $\mathrm{CO}_{2}$ at $39^{\circ} \mathrm{C}$.

The substrate, enzyme, and $\mathrm{EO}$ aliquots were added to serum bottles with $33 \mathrm{~mL}$ of mixed rumen liquor under a constant stream of $\mathrm{CO}_{2}$ to achieve $82.5 \mathrm{~mL} / \mathrm{g}$ substrate. They were then sealed with butyl rubber stoppers equipped with 1.5-inch needles and three-way stopcocks. After inoculation, the stopcock of every vial was opened for five seconds to release the small amount of gas that might have built up and create a starting point for the incubation. The vials were returned to the Incoshake incubator (Labotec (Pty) Ltd., Midrand, South Africa), which was set at $39^{\circ} \mathrm{C}$. Bottles that contained only mixed rumen liquor were used in each incubation run as blanks to correct for the gas produced as a result of rumen fluid. Four replicate bottles were incubated for the blank and for each treatment, and three repeat runs were carried out. Gas pressure was measured with a pressure transducer (PX4200-015GI, Omega Engineering, Inc., Laval, 
QC, Canada) as described by Theodorou et al. (1994) at 2, 4, 8, 12, 24, 36, and 48 hours after incubation. Gas samples were collected and analysed using a gas chromatograph equipped with a flame ionization detector (8610C BTU Gas Analyser GC System, SRI Instruments GmbH, Bad Honnef, Germany). After 48 hours of incubation, fermentation was terminated by placing all bottles on ice. In vitro organic matter digestibility (ivOMD) was determined according to the method of Tilley \& Terry (1963) as modified by Engels and Van der Merwe (1967).

Data were analysed as a randomized complete block design using the ANOVA procedure of SAS 9.4 (SAS Institute, Inc., Cary, North Carolina, USA). Blocks were defined as independent runs of the in vitro gas production system. Thus, the linear model included the effects of treatments and block. Significance was declared when $P<0.05$ and a tendency when $P \geq 0.05$ but $<0.1$. When there were significant differences between treatments, differences among the means were assessed using Tukey's test.

\section{Results and Discussion}

The inclusion of dietary additives did not affect in vitro gas production at 2 hours of incubation ( $P$ $>0.05$ ) (Table 1). However, at 4 hours of incubation and up to 48 hours, there were differences among the treatments $(P<0.05)$. T5 and T6 produced similar quantities of gas in vitro up to 48 hours incubation compared with T1. Generally, T2 had higher in vitro gas production from 8 hours to 48 hours incubation compared with $\mathrm{T} 1 \quad(P<0.05)$. Only a slight increase in the in vitro gas production could be associated with T3 and T4 across the incubation periods compared with T1.

Table 1 In vitro gas production of Eragrostis curvula hay treated with various enzyme and essential oil combinations over 48 hours

\begin{tabular}{lccccccc}
\hline \multirow{2}{*}{ Treatments } & \multicolumn{7}{c}{ Gas production (mL/g dry matter) at various hours of incubation } \\
\cline { 2 - 7 } & 2 & 4 & 8 & 12 & 24 & 36 & 48 \\
\hline T1 & 2.44 & $4.90^{\mathrm{ab}}$ & $11.7^{\mathrm{bc}}$ & $24.5^{\mathrm{b}}$ & $60.8^{\mathrm{bc}}$ & $93.3^{\mathrm{b}}$ & $118.3^{\mathrm{b}}$ \\
$\mathrm{T} 2$ & 4.51 & $7.88^{\mathrm{a}}$ & $15.6^{\mathrm{a}}$ & $29.1^{\mathrm{a}}$ & $67.0^{\mathrm{a}}$ & $100.1^{\mathrm{a}}$ & $125.0^{\mathrm{a}}$ \\
T3 & 3.46 & $6.31^{\mathrm{ab}}$ & $13.9^{\mathrm{ab}}$ & $27.3^{\mathrm{a}}$ & $64.1^{\mathrm{ab}}$ & $96.8^{\mathrm{ab}}$ & $121.0^{\mathrm{ab}}$ \\
$\mathrm{T} 4$ & 5.00 & $8.07^{\mathrm{a}}$ & $14.8^{\mathrm{ab}}$ & $27.1^{\mathrm{a}}$ & $63.6^{\mathrm{abc}}$ & $96.0^{\mathrm{ab}}$ & $121.0^{\mathrm{bb}}$ \\
$\mathrm{T} 5$ & 2.42 & $5.14^{\mathrm{ab}}$ & $11.8^{\mathrm{bc}}$ & $24.2^{\mathrm{b}}$ & $60.5^{\mathrm{bc}}$ & $93.1^{\mathrm{b}}$ & $116.9^{\mathrm{b}}$ \\
T6 & 2.19 & $4.08^{\mathrm{b}}$ & $10.58^{\mathrm{c}}$ & $22.7^{\mathrm{b}}$ & $59.8^{\mathrm{c}}$ & $92.1^{\mathrm{b}}$ & $116.0^{\mathrm{b}}$ \\
$\mathrm{SE}$ & 0.84 & 0.76 & 0.64 & 0.48 & 0.76 & 1.07 & 1.09 \\
P-value & 0.16 & 0.02 & $<0.01$ & $<0.01$ & $<0.01$ & $<0.01$ & $<0.01$ \\
\hline
\end{tabular}

T1: unaugmented control, T2: enzyme (cellulose-xylanase mixture), T3: enzyme combined with Next Enhance, T4: enzyme and cinnamon, T5: enzyme and garlic oil, T6: enzyme with cinnamon and garlic oil

${ }_{\text {a.b.c }}$ Within a column, means with a common superscript were not different with probability $P=0.05$

Dietary additives affected methane production from the Eragrostis curvula hay $(P<0.05)$ except at 24 hours and 36 hours incubation, when there was only a tendency towards significance $(P=0.07)$. Across the incubation periods, enzyme supplementation increased methane production compared with the control diet, but this was more pronounced in the early incubation period (up to 8 hours) (Table 2). The enzyme and EO additives affected 48 hours methane $(P=0.05)$. T5 and $\mathrm{T} 6$ reduced ivCH $\mathrm{H}_{4}$ compared with $\mathrm{T} 1$, although $\mathrm{T} 2$ did not affect 48 hour ivCH4 production. Nevertheless, T3 and T4 were not different from T1 or T2 in methane production. Furthermore, all treatments that contained EOs appeared to produce less $\mathrm{ivCH}_{4}$ during the early stages of the incubation period compared with T2. T4, T5 and T6 continued to produce less ivCH $\mathrm{ip}_{4}$ to 12 hours after incubation, with $\mathrm{T} 6$ producing less iv $\mathrm{CH} 4$ throughout the 48-hour period.

No differences were observed across treatments in in vitro organic matter digestibility (iVOMD), the ratio of methane to organic matter digestibility (ivCH $\mathrm{CH}_{4} / \mathrm{ivOMD}$ ), the ratio of methane to gas production (ivCH $\mathrm{in}_{4} / \mathrm{ivGP}$ ) and the ratio of gas production to organic matter digested (ivGP/ivOMD) following the 48 hour incubation period. However, there was a tendency for the additives to affect ivOMD ( $\mathrm{g} / \mathrm{kg} \mathrm{DM})(P=0.09)$, ivCH4/ivOMD ( $\mathrm{mL} / \mathrm{kg} \mathrm{DM})(P=0.07)$, and ivGP/ivOMD ( $\mathrm{mL} / \mathrm{kg} \mathrm{DM})(P=0.09)$ (Table 3). In vitro organic matter digestibility (IVOMD) was highest in T2 and lowest $\mathrm{T}$. Whereas iv $\mathrm{CH}_{4} / \mathrm{ivOMD}$ was highest in T2, it was 
lowest in T6. The digestion of Eragrostis curvula hay augmented with T5 and T3 had only slightly lower production of $\mathrm{ivCH}_{4} / \mathrm{ivOMD}$ compared with $\mathrm{T} 1$.

Table 2 Cumulative in vitro methane production from Eragrostis curvula treated with various enzyme and essential oil combinations over 48 hours

\begin{tabular}{lccccccc}
\hline \multirow{2}{*}{ Treatments } & \multicolumn{7}{c}{ Methane production (mL/g dry matter) at various hours of incubation } \\
\cline { 2 - 7 } & 2 & 4 & 8 & 12 & 24 & 36 & 48 \\
\hline T1 & $0.001^{\mathrm{b}}$ & $0.010^{\mathrm{b}}$ & $0.06^{\mathrm{b}}$ & $0.24^{\mathrm{ab}}$ & $1.43^{\mathrm{ab}}$ & $2.89^{\mathrm{ab}}$ & $4.19^{\mathrm{ab}}$ \\
$\mathrm{T} 2$ & $0.017^{\mathrm{a}}$ & $0.033^{\mathrm{a}}$ & $0.12^{\mathrm{a}}$ & $0.34^{\mathrm{a}}$ & $1.68^{\mathrm{a}}$ & $3.25^{\mathrm{a}}$ & $4.59^{\mathrm{a}}$ \\
$\mathrm{T} 3$ & $0.003^{\mathrm{b}}$ & $0.010^{\mathrm{b}}$ & $0.06^{\mathrm{b}}$ & $0.25^{\mathrm{ab}}$ & $1.42^{\mathrm{ab}}$ & $2.88^{\mathrm{ab}}$ & $4.15^{\mathrm{ab}}$ \\
$\mathrm{T} 4$ & $0.003^{\mathrm{b}}$ & $0.013^{\mathrm{b}}$ & $0.07^{\mathrm{b}}$ & $0.23^{\mathrm{b}}$ & $1.44^{\mathrm{ab}}$ & $2.91^{\mathrm{ab}}$ & $4.26^{\mathrm{ab}}$ \\
T5 & $0.003^{\mathrm{b}}$ & $0.010^{\mathrm{b}}$ & $0.06^{\mathrm{b}}$ & $0.22^{\mathrm{b}}$ & $1.34^{\mathrm{ab}}$ & $2.70^{\mathrm{ab}}$ & $3.90^{\mathrm{b}}$ \\
T6 & $0.001^{\mathrm{b}}$ & $0.003^{\mathrm{b}}$ & $0.05^{\mathrm{b}}$ & $0.20^{\mathrm{b}}$ & $1.26^{\mathrm{b}}$ & $2.59^{\mathrm{b}}$ & $3.89^{\mathrm{b}}$ \\
SEM & 0.01 & 0.01 & 0.01 & 0.02 & 0.08 & 0.13 & 0.14 \\
$P$-value & $<0.01$ & $<0.01$ & $<0.01$ & 0.02 & 0.07 & 0.06 & 0.05 \\
\hline
\end{tabular}

T1: unaugmented control, T2: enzyme (cellulose-xylanase mixture), T3: enzyme combined with Next Enhance, T4: enzyme and cinnamon, T5: enzyme and garlic oil, T6: enzyme with cinnamon and garlic oil

${ }_{\text {a.b.c }}$ Within a column, means with a common superscript were not different with probability $P=0.05$

Table 3 In vitro organic matter digestibility and the relationship between methane, gas production and organic matter digestibility in vitro after 48 hours of incubating Eragrostis curvula with essential oils and fibrolytic enzymes

\begin{tabular}{lcccc}
\hline Treatments & ivOMD, g/kg DM & ivCH $_{4} /$ ivOMD, $\mathrm{mL} / \mathrm{kg} \mathrm{DM}$ & ivCH $_{4} / \mathrm{ivGP}, \mathrm{mL} / \mathrm{mL}$ & ivGP/ivOMD, $\mathrm{mL} / \mathrm{kg} \mathrm{DM}$ \\
\hline T1 & 488 & 8.53 & 3.52 & 241 \\
T2 & 507 & 8.97 & 3.64 & 246 \\
T3 & 495 & 8.32 & 3.41 & 245 \\
T4 & 494 & 8.56 & 3.49 & 245 \\
T5 & 492 & 7.88 & 3.32 & 237 \\
T6 & 493 & 7.82 & 3.31 & 235 \\
SE & 0.38 & 0.26 & 0.10 & 2.82 \\
$P$-value & 0.09 & 0.07 & 0.26 & 0.09
\end{tabular}

T1: unaugmented control; T2: enzyme (cellulose-xylanase mixture); T3: enzyme combined with Next Enhance; T4: enzyme and cinnamon; T5: enzyme and garlic oil; T6: enzyme with cinnamon and garlic oil; ivOMD; in vitro organic matter digestibility; iv $\mathrm{CH}_{4}$ : in vitro methane; ivGP: in vitro gas production

The low nutritive value of Eragrostis hay was an indication that higher methane output per unit of feed consumed could be expected as a result of the associated low productivity of animals that consumed this feedstuff. Therefore, in supplementation with additives that could improve dry matter degradability and reduce methane emission, a loss of feed energy would guarantee its improved utilization for sustainable livestock production. In the early incubation period, enzyme supplementation resulted in only a slight increase in ivGP, but EO supplementation, especially cinnamon and garlic oils, reduced ivGP. Previous studies showed that higher ivGP was observed in the early incubation intervals with exogenous enzyme treatment of lucerne forage (Colombatto et al., 2007), sugarcane leaves and sorghum straw (Elghandour et al., 2013), and in a grass hay/concentrate substrate (Giraldo et al., 2008). Higher ivGP has been used to validate the effect of fibrolytic enzyme in improving the digestibility of feedstuffs (Cantet et al., 2016). Fibrolytic enzymes act on the slowly but progressively fermentable fraction of feed DM (largely the NDF and 
ADF) through reduction in cell wall thickness (Van de Vyer \& Cruywagen, 2013), allowing rumen microbes and fermentation enzymes an easier access to plant cell constituents (Pinos-Rodríguez et al., 2008). Unlike T5 and T6, T2 resulted in a significant increase in 24 hour and 48 hour cumulative ivGP. It appears that the hemicellulose of the cell wall components was degradable more consistently in reported studies, largely because of the initial consumption of carbohydrates through the activities of endo- and exo-glucanase enzymes, with cellulose being degraded to a lesser degree, whereas lignin was undegraded (Rodrigues et al., 2008). This was evident in the higher gas production observed after 12 hours incubation, unlike the early incubation period.

The various growth media in which enzymes were produced and the differences in strains usually resulted in a wide variation in response to enzyme supplementation across various trials (Castro-Montoya et al., 2015). The enzyme product used in the current study was a 1:1 mixture of cellulose and xylanase enzymes. Although the potential synergistic effects of two or more enzymes in cell wall degradation was noted by De Vries et al., (2000), improvements in the ivOMD, neutral detergent fibre (NDF) and crude protein (CP) degradability after the addition of these multienzyme products were variable. Whereas enzyme supplementation improved DM, NDF and CP digestibility in a dairy cow diet (Elghandour et al., 2013), Jalilvand et al. (2008) did not observe any differences in gas production with the addition of exogenous enzyme mixtures (cellulase, xylanase, alpha-glucanase, protease and amylase) to lucerne hay, wheat straw and maize silage. Diet type and differences in enzyme activity may account for wide variations in the potency of enzyme products, even when supplemented at the same concentration. Nevertheless, Colombatto et al. (2007) noted that exogenous enzyme treatments tended to increase cellulose and xylan degradability in vitro, owing primarily to greater colonization of cell wall surfaces by enzymes. The ability of cellulases and xylanases to increase the extent of fibre digestion may be limited by the lack of enzymes that degrade the core structure of lignin-cellulose complexes in low-quality forages (Carro et al., 2007).

The strong antiseptic properties of cinnamon and garlic oils exert an antimethanogenic effect on rumen fermentation, as evidenced by the tendency to reduce ivCH $\mathrm{CH}_{4}$ in the current study. Cinnamaldehyde is the main active agent in the commercial EO compound and cinnamon oil treatments (Khorrami et al., 2015). The antimicrobial activity of cinnamaldehyde has been linked to the reactivity of its carbonyl group, although the mechanism of antimethanogenic action is not known fully (Calsamiglia et al., 2007). Equally, garlic oil is known to contain organosulfur compounds such as alliin and allicin, diallyl sulphide, diallyl disulphide (DADS) and allyl mercaptan as bioactive compounds (Patra \& Yu, 2012; Pawar et al., 2014). However, diallyl disulfide and allyl mercaptan were noted to be responsible for most of the effects on rumen fermentation (Busquet et al., 2005). Although numerous studies have been conducted on the use of EOs in ruminant nutrition, the results have varied widely (McGinn et al., 2004; Busquet et al., 2005; Klevenhusen et al., 2011) and the arguments against the comparison of results between studies can be justified because few studies involve identical EO compositions (Castro-Montoya et al., 2015). The bioactive compounds in EOs vary in chemical structure and stereochemistry, and therefore tend to alter rumen microbial population differently (Calsamiglia et al., 2007).

Although previous reports on the antimethanogenic effects of EOs showed some promise, the results varied widely and were inconsistent. Klevenhusen et al. (2011) supplemented DADS, a principal organosulfur compound, in garlic oil at $2 \mathrm{~g} / \mathrm{kg} \mathrm{DM}$ in sheep ration and did not observe any significant effect on methane emissions, although an in vitro study by Busquet et al. (2005) showed significant methane suppression with DADS at $300 \mathrm{mg} / \mathrm{L}$ inclusion level. In the study by Pawar et al. (2014), garlic and cinnamon oils at $167 \mu \mathrm{L} / \mathrm{L}$ of incubation media reduced in vitro methane production significantly without negative effects on the organic matter digestibility of the wheat straw and concentrate mixture. Equally, Patra and $\mathrm{Yu}$ (2012) observed significantly reduced methane production with increasing doses of garlic oil from $0.25 \mathrm{~g} / \mathrm{L}$, with 1.0 $\mathrm{g} / \mathrm{L}$ showing a $42 \%$ decrease in the in vitro methane production without any significant depression in DM and NDF degradability. The effect of cinnamon oil as a rumen modifier in beef steers showed that $500 \mathrm{mg} / \mathrm{kg} \mathrm{DM}$ cinnamon oil did not depress nutrient digestibility or alter rumen fermentation, but reduced the relative abundance of protozoa and methanogenic archaea (Khorrami et al., 2015). In a similar study, horseradish oil modulated rumen fermentation in Holstein steers effectively by reducing acetate and increasing propionate of volatile fatty acids (VFAs), while decreasing methane production by $19 \%$ and showing a significant reduction in the methanogen population of the rumen (Mohammed et al., 2004). The $\mathrm{pH}$ of rumen or in vitro incubation media, which is influenced by diet type, greatly affects the efficacy of EOs.

Cardozo et al. (2005) observed that garlic oil supplementation of a high concentrate beef ration showed that at $\mathrm{pH} 7.0$, ammonia nitrogen and total VFA concentration decreased compared with the control. However, at a $\mathrm{pH}$ of 5.5, although ammonia nitrogen concentration decreased, total VFA concentration increased, and there was a shift in the molar proportion of VFA from acetate to propionate. This variation in response was related to the higher susceptibility of microbes to the effects of EOs at low pH (Skandamis \& Nychas, 2000) with lower pH being associated more with animals that consumed high concentrate diets. In 
this study, rumen fluid was obtained from donor sheep that consumed lucerne and therefore the impact of EOs on rumen fermentation might be less observable. The presence and relative position of a hydroxyl group in the phenolic structures of EOs have been noted as being capable of influencing the antimicrobial potency of EOs in the rumen (Ultee et al., 2002). Garlic oil exerted a more inhibitory effect on methanogenic archaea than on rumen bacterial populations. This was associated with the effect of its organosulfur compounds in inhibiting the HMG-CoA reductase enzymes, which are responsible for the synthesis of isoprenoid side chains in the archaeal cell membrane lipids (Busquet et al., 2006; Calsamiglia et al., 2007; Kamel et al., 2008).

Although there have been few studies on the potential interaction effect of exogenous polysaccharide degrading enzyme and plant phytochemicals on rumen fermentation (Salem et al., 2015), the current study did not show a significant additive effect between enzyme and EO inclusion in reducing methane or improving digestibility. Nevertheless, the tendency to reduce methane without depressing organic digestibility justifies further studies on the optimal doses of cinnamon and garlic oils for practical application with poorquality roughage feed such as the Eragrostis curvula hay.

\section{Conclusion}

The addition of an exogenous fibrolytic enzyme increased in vitro gas production, but a methane suppressing effect was not observed, even when augmented with an EO. However, there was a tendency for augmentation with garlic oil alone or in combination with cinnamon to reduce in vitro methane production after 48 hours incubation. Organic matter digestibility was not affected by the inclusion of additives. The combination of EOs with anti-methanogenic effects and that do not depress organic matter digestibility would seemingly have application in sustainable ruminant systems. A combination of an exogenous fibrolytic enzyme and garlic oil, at higher doses, is recommended for further in vitro and in vivo evaluation.

\section{Acknowledgements}

The study was carried out through funding support from the Department of Science and Technology and National Research Foundation, South Africa.

\section{Authors' Contributions}

TCN and AH designed the study. TCN did data collection and TCN, AH and AMA did data analysis. TCN and FAA wrote the draft manuscript and AMA and AH did the editing and proofreading. AH funded and supervised the study.

\section{Conflict of Interest Declaration}

The authors declare that there was no conflict of interest in the conduct of this study.

\section{References}

Beauchemin, K.A., Kreuzer, M., O'Mara, F. \& McAllister, T.A., 2008. Nutritional management for enteric methane abatement: A review. Aust. J. Exp. Agric. 48, 21-27. https://doi.org/10.1071/EA07199

Benchaar, C. \& Greathead, H., 2011. Essential oils and opportunities to mitigate enteric methane emissions from ruminants. Anim. Feed Sci. Technol. 166-167, 338-355. https://doi.org/10.1016/j.anifeedsci.2011.04.024

Benchaar, C., Petit, H.V., Berthiaume, R., Ouellet, D.R., Chiquette, J. \& Chouinardt, P.Y., 2007. Effects of essential oils on digestion, ruminal fermentation, rumen microbial populations, milk production, and milk composition in dairy cows fed alfalfa silage or corn silage. J. Dairy Sci. 90, 886-897. https://doi.org/10.3168/jds.S0022-0302(07)715722

Busquet, M., Calsamiglia, S., Ferret, A., Carro, M.D. \& Kamel, C., 2005. Effect of garlic oil and four of its compounds on rumen microbial fermentation. J. Dairy Sci. 88, 4393-4404. https://doi.org/10.3168/jds.S0022-0302(05)73126-X.

Busquet, M., Calsamiglia, S., Ferret, A. \& Kamel, C., 2006. Plant extracts affect in vitro rumenmicrobial fermentation. J. Dairy Sci. 89, 761-771.

Calsamiglia, S., Busquet, M., Cardozo, P.W., Castillejos, L. \& Ferret, A., 2007. Invited review: Essential oils as modifiers of rumen microbial fermentation. J. Dairy Sci. 90, 2580-2595. https://doi.org/10.3168/jds.2006-644

Cantet, J.M., Colombatto, D. \& Jaurena, G., 2016. Methane production and in vitro digestibility of low quality forages treated with a protease or a cellulase. Anim. Prod. Sci. 56, 1700-1706. https://doi.org/10.1071/AN14988.

Carro, M.D., Giraldo, L.A., Mohamed, A.H, Ranilla, M.J. \& Tejido, M.L., 2007. In vitro ruminal fermentation of low-quality forages as influenced by the treatment with exogenous fibrolytic enzymes. In: A. Priolo, L. Biondi, H. Ben Salem \& P. Morand-Fehr ( eds). Advanced nutrition and feeding strategies to improve sheep and goat. CIHEAM, Zaragoza. Pp., 263-267.

Castro-Montoya, J., Peiren, N., Cone, J.W., Zweifel, B., Fievez, V. \& De Campeneere, S., 2015. In vivo and in vitro effects of a blend of essential oils on rumen methane mitigation. Livest. Sci. 180, 134-142. https://doi.org/10.1016/j.livsci.2015.08.010

Colombatto, D., Mould, F.L., Bhat, M.K. \& Owen, E., 2007. Influence of exogenous fibrolytic enzyme level and incubation $\mathrm{pH}$ on the in vitro ruminal fermentation of alfalfa stems. Anim. Feed Sci. Technol. 137, 150-162.

De Vries, R.P., Kester, H.C.M., Poulsen, C.H., Benen, J.A.E. \& Visser, J., 2000. Synergy between enzymes from Aspergillus involved in the degradation of plant cell wall polysaccharides. Carbohydr. Res. 327, 401-410. 
https://doi.org/10.1016/S0008-6215(00)00066-5

Elghandour, M.M.Y., Salem, A.Z.M., Ganzalez-Ronquillo, M., Bórquez, J.L., Gado, H.M., Odongo, N.E. \& Peñuelas, C. G., 2013. Effects of exogenous enzymes on in vitro gas production kinetics and ruminal fermentation of four fibrous feeds. Anim. Feed Sci. Technol. 179, 46-53.

Engels, E.A.N. \& Van Der Merwe, F.J., 1967. Application of an in vitro technique to South African forages with special reference to the effect to certain factors on the results. S. Afr. J. Agric. Sci. 10, 983-995.

Gemeda, B.S., Hassen, A. \& Odongo, N.E., 2014. Effect of fibrolytic enzyme products at different levels on in vitro ruminal fermentation of low quality feeds and total mixed ration. J. Anim. Plant Sci., 24(5): 1293-1302.

Gemeda, B.S. \& Hassen, A., 2015. Methane production of two roughage and total mixed ration as influenced by cellulase and xylanase enzyme addition. Scientia Agricola 72(1): 11-19.

Giraldo, L., Tejido, M., Ranilla, M. J., Ramos, S. \& Carro, M., 2008. Influence of direct-fed fibrolytic enzymes on diet digestibility and ruminal activity in sheep fed a grass hay-based diet. J. Anim. Sci. 86, 1617-1623.

Goering, H.K.\& Van Soest, P.J., 1970. Forage fiber analysis (apparatus, reagents, procedures, and some applications). USDA Agric. Res. Serv. Handb. No. 379.

Jalilvand, G., Odongo, N., López, S., Naserian, A., Valizadeh, R., Sharodi, F., Kebreab, E. \& France, J., 2008. Effects of different levels of an enzyme mixture on in vitro gas production parameters of contrasting forages. Anim. Feed Sci. Technol. 146, 289-301.

Kamel, C., Greathead, H., Tejido, M., Ranilla, M. \& Carro, M., 2008. Effects of allicin and diallyl disulfide on in vitro rumen fermentation of a mixed diet. Anim. Feed Sci. Technol. 145, 351-363.

Khorrami, B., Vakili, A.R., Mesgaran Danesh, M., Klevenhunsen, F., 2015. Thyme and cinnamon essential oils: Potential alternatives for monensin as a rumen modifier in beef production systems. Anim. Feed Sci. Technol. 200, 8-16.

Klevenhusen, F., Zeitz, J., Duval, S., Kreuzer, M., Soliva, C.R., 2011. Garlic oil and its principal component diallyl disulfide fail to mitigate methane, but improve digestibility in sheep. Anim. Feed Sci. Technol. 166, 356-363.

McGinn, S., Beauchemin, K.K.A., Coates, D. \& Colombatto, D., 2004. Methane emissions from beef cattle: Effects of monensin, sunflower oil, enzymes, yeast, and fumaric acid. J. Anim. Sci. 82, 3346-3356. https://doi.org/10.2527/2004.82113346x

McIntosh, F.M., Williams, P., Losa, R., Wallace, R.J., Beever, D.A. \& Newbold, C.J., 2003. Effects of essential oils on ruminal microorganisms and their protein metabolism. Appl. Environ. Microbiol. 69, 5011-5014. https://doi.org/10.1128/AEM.69.8.5011

Mohammed, N., Ajisaka, N., Lila, Z., Hara, K., Mikuni, K., Kanda, S., Itabashi, H., Mohammad, N., Ajisaka, N. \& Lila, Z., 2004. Effect of Japanese horseradish oil on methane production and ruminal fermentation in vitro and in steers. J. Anim. Sci. 82, 1839-1846.

Mould, F.L., Kliem, K.E., Morgan, R. \& Mauricio, R.M., 2005. In vitro microbial inoculum: A review of its function and properties. Anim. Feed Sci. Technol. 123-124, 31-50. https://doi.org/10.1016/j.anifeedsci.2005.04.028

Mutavhatsindi, T.F., Nkosi, B.D., Baloyi, J.J. \& Langa, T., 2018. Effects of a fibrolytic enzyme and bacterial inoculants on the fermentation, chemical composition and aerobic stability of ensiled potato hash. S. Afr. J. Anim. Sci. 48, 244252. https://doi.org/10.4314/sajas.v48i2.5

Ouwehand, A.C., Tiihonen, K., Kettunen, H., Peuranen, S., Schulze, H. \& Rautonen, N., 2010. In vitro effects of essential oils on potential pathogens and beneficial members of the normal microbiota. Vet. Med. (Praha) 55, 71-78. https://doi.org/10.17221/152/2009-VETMED

Patra, A.K. \& Yu, Z., 2012. Effects of essential oils on methane production and fermentation by, and abundance and diversity of, rumen microbial populations. Appl. Environ. Microbiol. 78, 4271-4280. https://doi.org/10.1128/AEM.00309-12

Pawar, M.M., Kamra, D.N., Agarwal, N. \& Chaudhary, L.C., 2014. Effects of essential oils on in vitro methanogenesis and feed fermentation with buffalo rumen liquor. Agric. Res. 3, 67-74. https://doi.org/10.1007/s40003-014-0092-z

Pinos-Rodríguez, J.M., Moreno, R., González, S.S., Robinson, P.H., Mendoza, G. \& Álvarez, G., 2008. Effects of exogenous fibrolytic enzymes on ruminal fermentation and digestibility of total mixed rations fed to lambs. Anim. Feed Sci. Technol. 142, 210-219. https://doi.org/10.1016/j.anifeedsci.2007.08.005

Rodrigues, M.A.M., Pinto, P., Bezerra, R.M.F., Dias, A.A., Guedes, C.V.M., Cardoso, V.M.G., Cone, J.W., Ferreira, L.M.M., Colaço, J. \& Sequeira, C.A., 2008. Effect of enzyme extracts isolated from white-rot fungi on chemical composition and in vitro digestibility of wheat straw. Anim. Feed Sci. Technol. 141, 326-338. https://doi.org/10.1016/j.anifeedsci.2007.06.015

Salem, A.Z.M., Buendia-Rodriguez, G., Elghandour, M.M.M., Berasain, M.A.M., Jimennez, F.J.P., Pliego, A.B., Chagoyan, J.C.V. \& Cerrillo, M.A.R., 2015. Effects of cellulase and xylanase enzymes mixed with increasing doses of Salix babylonica extract on in vitro rumen gas production kinetics of a mixture of corn silage with concentrate. J. Integrative Agric. 14(1),131-139.

Skandamis, P.N. \& Nychas, G.J.E., 2000. Development and evaluation of a model predicting the survival of Escherichia coli 0157:H7 NCTC 12900 in homemade eggplant salad at various temperatures, pHs, and oregano essential oil concentrations. Appl. Environ. Microbio. 66(4), 1646-1653.

Theodorou, M.K., Williams, B.A., Dhanoa, M.S., McAllan, A.B. \& France, J., 1994. A simple gas production method using a pressure transducer to determine the fermentation kinetics of ruminant feeds. Anim. Feed Sci. Technol. 48, 185-197. https://doi.org/10.1016/0377-8401(94)90171-6

Tilley, J.M.A. \& Terry, R.A., 1963. A two-stage technique for the in vitro digestion of forage crops. Grass Forage Sci. 18, 104-111. https://doi.org/10.1111/j.1365-2494.1963.tb00335.x

Ultee, A., Bennink, M. \& Moezelaar, R., 2002. The phenolic hydroxyl group of carvacrol is essential for action against the food-borne pathogen Bacillus cereus. Appl. Environ. Microbiol., 1561-1568. 
Van de Vyver, W.F.J. \& Cruywagen, C.W.C., 2013. Exogenous fibrolytic enzymes to unlock nutrients: Histological investigation of its effects on fibre degradation in ruminants. S. Afr. J. Anim. Sci. 43, S55-S59. https://doi.org/10.4314/sajas.v43i5.10

Wallace, R.J., 2004. Antimicrobial properties of plant secondary metabolites. Proc. Nutr. Soc. 63, 621-629. https://doi.org/10.1079/PNS2004393

Wink, M., 2010. Functions of plant secondary metabolites and their exploitation in biotechnology.; Volume 39. Annu. Plant Rev. 39. Wiley-Blackwell, London, UK. 